\title{
Structural and Mechanical Properties of Chitosan Doped with Zirconium Oxide
}

\author{
${ }^{* 1}$ M. S. Sikder, ${ }^{1}$ M. R. Rahman, ${ }^{2}$ M. Al-Mamun, ${ }^{3}$ M. S. S. Chowdhury, ${ }^{2}$ M. M. Haque \\ ${ }^{1}$ Physics Discipline, Khulna University, Khulna, Bangladesh \\ ${ }^{2}$ Materials Science Division, Atomic Energy Centre, Dhaka, Bangladesh \\ ${ }^{3}$ Plasma Physics Division, Atomic Energy Centre, Dhaka, Bangladesh
}

\begin{abstract}
In this work, chitosan (CTS) powder has been doped with zirconium oxide $\left(\mathrm{ZrO}_{2}\right)$ at different wt.\% in order to improve the mechanical strength of the composites for biomedical applications. The composites have been prepared by ball milling method and the sintering has been done at three temperatures $100^{\circ} \mathrm{C}, 150^{\circ} \mathrm{C}$ and $180^{\circ} \mathrm{C}$ for 3 hours in air. The crystalline structure of the composites was confirmed by X-ray diffraction (XRD) pattern and the crystallite size of the composites decreases with increasing the percentage of $\mathrm{ZrO}_{2}$ and sintering temperature. The improvement of mechanical strength of the composites with the addition of $\mathrm{ZrO}_{2}$ in CTS polymer matrix has been investigated using micro-Vickers hardness tester and observed that the hardness of the prepared composite increased to $536 \mathrm{MPa}$ when $90 \mathrm{wt} . \%$ CTS doped with $10 \mathrm{wt} \% \mathrm{ZrO}_{2}$ at $180^{\circ} \mathrm{C}$ of sintering temperature, demonstrating that the composites can be a potential candidate in bone tissue engineering.
\end{abstract}

Keywords: Chitosan, zirconium oxide, ball milling, XRD, Vickers hardness.

\section{INTRODUCTION}

In orthopedic implants, the autografts and allografts have played a great role for the treatment of various orthopedic disorders originated by disease or trauma. These traditional processes of treatment are very expensive and have a great possibility of improper healing from invasive surgeries, infections, inadequate bone donations for sealing void space completely, and morbidity for donor site [1]. Bone tissue engineering is an alternative strategical approach to regenerate bone over allografting and autografting [1,2]. Nowadays, bone tissue engineering has successfully solved all kinds of shortages of clinical treatments like morbidity caused by donor site, limitations of availability, rejection of immunity, and pathogenic transformation. As human bone tissue is a nanocomposite which is a mixture of collagen (main organic component) and hydroxyapatite (inorganic component), it is expected to develop appropriate biomimetric nanocomposites for bone tissue engineering [3, 4]. The ideal nanocomposite should have multi- functionality such as biocompatibility, suitable antimicrobial and mechanical properties, nontoxicity and surface functionality to favor cell proliferation $[5,6]$.

With a view to developing multifunctional nanocomposites, many types of polymer-ceramic composites can be used in which CTS and hydroxyapatite (HAP) are very good bioactive biomaterials in bone tissue engineering. Furthermore, chitosan offers several advantages in biomedical applications, such as biocompatibility, biodegradability, and that degradation products do not produce inflammatory reactions or toxic degradation products (i.e., its degradability products are nontoxic, noncarcinogenic, and nonimmunogenic) $[7,8,9]$. Due to its unique polycationic nature, controlled biodegradability, biocompatibility, nontoxicity and bioresorbable nature, CTS has wide application in medical fields for applications such as gene therapy (drug or gene delivery), wound dressing, tissue engineering, blood anticoagulant, hypocholesterolemic agents, antithrombogenic agents, bone regeneration biomaterials, and antimicrobial agents [10-14]. Addition of HAP with CTS, improves its ostioconductivity [15, 16] but due to its brittle 
nature it hinders its random use in mechanically susceptible bone tissue engineering application [16]. Improved mechanical and thermal properties have already observed after the addition of montmorillonite (MMT) to polymer matrix [17]. From study, it has been found that a little amount of steps have been taken to fabricate the biomimetric nanocomposites containing CTS, MMT and HAP [18]. Kar et al., synthesized CTS-organically modified MMT (OMMT)-HAP composite scffold and increase in tensile strength of composite (0.56 MPa) over pure CTS (0.36 MPa) and CTS-OMMT (0.38 MPa) was observed [19].

In view of the above considerations, it is clear that worldwide scientists are trying to enhance the mechanical strength of CTS by adding appropriate materials with them. Such composites will remarkably improve mechanical properties including hardness, tensile strength etc. which is important for biomedical applications. $\mathrm{ZrO}_{2}$ can be considered as the prominent doping material because of its chemical stability, higher mechanical strength compared with HAP [20, 21]. Along with the suitable mechanical properties, osteoblast cell proliferation on $\mathrm{ZrO}_{2}$ has been observed without having any cytotoxicity [18]. In the present work, an attempt has been made to enhance the Vickers hardness of CTS doped with $\mathrm{ZrO}_{2}$ with the variation of sintering temperatures for biomedical applications. The composites have been prepared by ball milling method at the Materials Science Division of Atomic Energy Center, Dhaka (AECD), Bangladesh. A total number of 15 composites have been prepared with different wt.\% of CTS and $\mathrm{ZrO}_{2}$. Then each composite has been sintered at three different temperatures $100^{\circ} \mathrm{C}, 150^{\circ} \mathrm{C}$ and $180^{\circ} \mathrm{C}$ for 3 hours in air. XRD and Vickers hardness of the prepared composites were then investigated

\section{MATERIALS AND METHOD}

\subsection{Materials}

The materials used in this work were $3 \mathrm{~mol} \% \mathrm{Y}_{2} \mathrm{O}_{3}$ stabilized $\mathrm{ZrO}_{2}$ (designed $3 \mathrm{YSZ}$ purity $99.9 \%$, average particle size $40 \mathrm{~nm}$, US Research Nanomaterials, Inc.) and a polysaccharide named chitosan (90\% D.A.C and bulk density is 0.3, Biorigins, mystic moments, UK.). All chemicals were collected by AECD, Bangladesh.

\subsection{Sample preparation}

The composites of CTS and $\mathrm{ZrO}_{2}$ were synthesized by ball-milling method for 4 hours in air medium, using high purity zirconia balls (10 mm diameter) to obtain a homogeneous mixture. The milling was carried out in a RETSCH ball mill (0-1000 rev/min). The addition of $\mathrm{ZrO}_{2}$ was varied as $2-10 \mathrm{wt} . \%$ in step of 2 and chitosan was varied as $98-90 \mathrm{wt} \%$ in step of 2 respectively. The powder was crushed gently with the help of mortar and pestle to get proper mixing for half an hour. Then the powder was pressed to make circular pellets of $10 \mathrm{~mm}$ diameter with WEBER PRESSEN hydraulic pressure gauge under a force of $10 \mathrm{KN}$ and labeled. Finally, the synthesized composites were sintered at $100^{\circ} \mathrm{C}, 150^{\circ} \mathrm{C}$ and $180^{\circ} \mathrm{C}$ for 3 hours in air in Nabertherm sintering machine. All the instruments are established at AECD, Bangladesh.

\subsection{Characterization}

The powder XRD pattern of the samples were performed using PHILIPS X' Pert PRO PW 3040 X-ray diffractometer with $\mathrm{Cu} \mathrm{K} \alpha$ radiation $(\lambda=1.5405 \AA)$. The hardness of the sintered samples was evaluated at room temperature by a micro-Vickers hardness tester (Shimadzu, HMV-2, Japan).

\section{RESULTS AND DISCUSSION}

\subsection{XRD analysis}

The phase structures of $3 \mathrm{~mol} \% \mathrm{Y}_{2} \mathrm{O}_{3}$ stabilized $\mathrm{ZrO}_{2}$ (3YSZ), CTS powder and as-synthesized samples were determined by XRD and shown in fig. 1. For simplicity, XRD patterns of only six prepared composites among fifteen are presented here. It is clear from XRD patterns (a to $\mathrm{h}$ in fig. 1) that the pure and prepared elements are crystalline in nature. From fig. 1 , it is also observed that the $\mathrm{ZrO}_{2}$ was purely tetragonal (t) in nature where the diffraction peaks appeared at $2 \theta=30.4^{\circ}, 51.01^{\circ}$ and $59.30^{\circ}$ are assigned to the (101), (112) and (103) reflection planes respectively. Besides tetragonal, few amount of monoclinic (m) phase of $\mathrm{ZrO}_{2}$ was observed, which were 
characterized by diffraction peaks approximately at $2 \theta=28^{\circ}$ and $2 \theta=31^{\circ}$. As CTS is almost an amorphous polymer, it has poor crystallinity. The XRD pattern of standard CTS procured from sigma Aldrich shows the peaks around $2 \theta=10^{\circ}$ and $2 \theta=20^{\circ}$ are related to crystal I and crystal II in

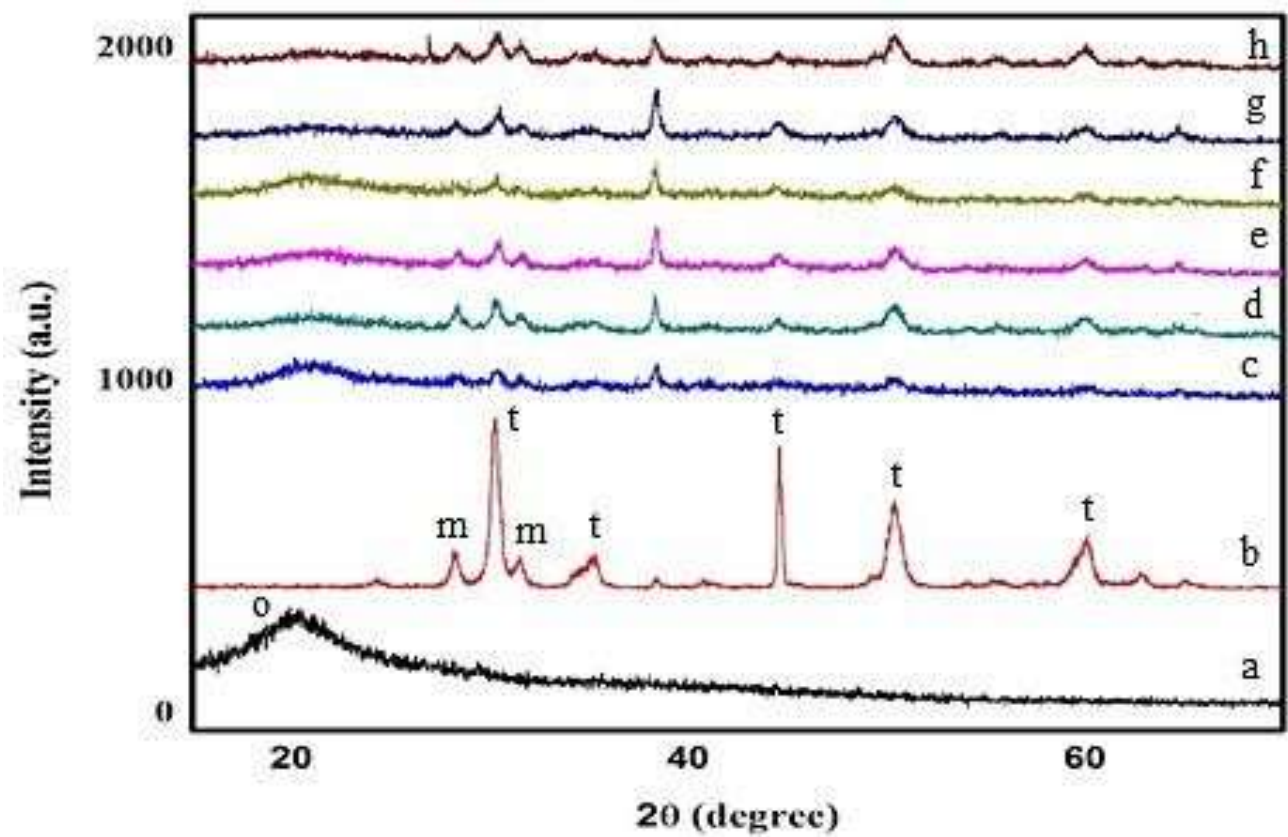

Figure 1: $\mathrm{X}$-ray diffraction profiles of (a) chitosan (b) $3 \mathrm{~mol} \% \mathrm{Y}_{2} \mathrm{O}_{3}$ stabilized $\mathrm{ZrO}_{2}$ (3Y-SZ)

(c) $94 \mathrm{wt} . \%$ chitosan-6wt. $\% \mathrm{ZrO}_{2}$ sintered at $100^{\circ} \mathrm{C}$ (d) $90 \mathrm{wt} . \%$ chitosan-10wt. $\% \mathrm{ZrO}_{2}$ sintered at $100^{\circ} \mathrm{C}$

(e) $94 \mathrm{wt} . \%$ chitosan-6wt. $\% \mathrm{ZrO}_{2}$ sintered at $150^{\circ} \mathrm{C}$ (f) $90 \mathrm{wt} . \%$ chitosan-10wt. $\% \mathrm{ZrO}_{2}$ sintered at $150^{\circ} \mathrm{C}$

(g) $94 \mathrm{wt} . \%$ chitosan-6wt. $\% \mathrm{ZrO}_{2}$ sintered at $180^{\circ} \mathrm{C}$ (h) $90 \mathrm{wt} . \%$ chitosan $10 \mathrm{wt} . \% \mathrm{ZrO}_{2}$ sintered at $180^{\circ} \mathrm{C}$

$\mathrm{o}=$ orthorhombic, $\mathrm{t}=$ tetragonal, $\mathrm{m}=$ monoclinic

CTS structure and both these peaks attributes a high degree of crystallinity [22-24]. In this study, the peak at $2 \theta=$ $20^{\circ}$ displayed the crystalline structure of CTS. The typical peak of CTS shifted from $2 \theta=20^{\circ}$ to $2 \theta=21^{\circ}$ as shown in fig. 1, due to the intercalation of $\mathrm{ZrO}_{2}$ into CTS structure. At higher sintering temperature the peak at $2 \theta=20^{\circ}$ almost vanished, indicating that $\mathrm{ZrO}_{2}$ has been mixed very well with CTS and blocked the peak. The CTS peak becomes flat and the $\mathrm{ZrO}_{2}$ peaks are more prominent at $180^{\circ} \mathrm{C}$ than that of $150^{\circ} \mathrm{C}$ and $100^{\circ} \mathrm{C}$, representing that the sintering is proper in this temperature. The crystallite size of the samples having configuration $\mathrm{g}$ and $\mathrm{h}$ (fig. 1) have been calculated using Debye-Scherrer formula[25] and found $25.75 \mathrm{~nm}$ and $17.06 \mathrm{~nm}$ respectively, showing that the crystallite size decreases with increasing the sintering temperature and the percentage of $\mathrm{ZrO}_{2}$ in the composites. 
International Journal of Advances in Scientific Research and Engineering (ijasre), Volume 6 (7)，July -2020

\subsection{Vickers hardness analysis}

Hardness characterizes the state of a material under test and gives information about the character of the chemical bonding. It is basically related to the structure and strength of the material. The Vickers hardness of as-synthesized composites and CTS powder at three different sintering temperatures are summarizing in table 1 and fig. 2, which shows that the hardness of the composites is larger than that of pure CTS. From table 1 and fig. 2, it is also revealed that the

Table 1: Vickers hardness (MPa) of CTS and prepared composites at different sintering temperatures

\begin{tabular}{|c|c|c|c|c|c|c|}
\hline \multirow{2}{*}{$\begin{array}{l}\text { Sintering } \\
\text { temp. } \\
\left({ }^{\circ} \mathrm{C}\right)\end{array}$} & \multicolumn{6}{|c|}{ Vickers hardness (MPa) } \\
\hline & CTS & $\begin{array}{r}98 \% \mathrm{CTS} \\
+2 \% \mathrm{ZrO}_{2}\end{array}$ & $\begin{array}{r}96 \% \mathrm{CTS} \\
+4 \% \mathrm{ZrO}_{2}\end{array}$ & $\begin{array}{r}94 \% \mathrm{CTS} \\
+6 \% \mathrm{ZrO}_{2}\end{array}$ & $\begin{array}{r}92 \% \text { CTS } \\
+8 \% \mathrm{ZrO}_{2}\end{array}$ & $\begin{array}{r}90 \% \mathrm{CTS} \\
+10 \% \mathrm{ZrO}_{2}\end{array}$ \\
\hline 100 & 242 & 242 & 260 & 272 & 292 & 300 \\
\hline 150 & 245 & 248 & 262 & 265 & 323 & 343 \\
\hline 180 & 258 & 259 & 277 & 317 & 379 & 536 \\
\hline
\end{tabular}

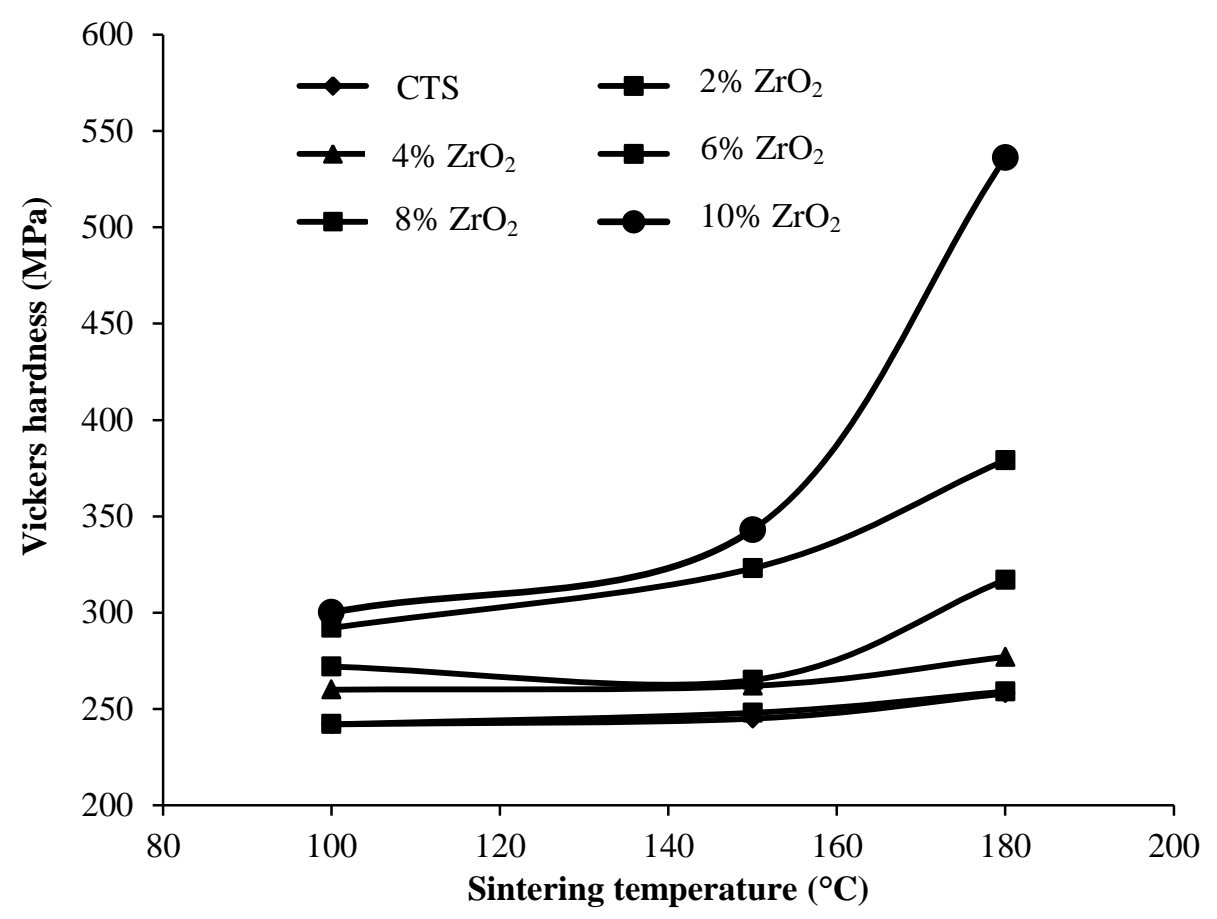

Figure 2: Vickers hardness of pure CTS and the prepared CTS- $\mathrm{ZrO}_{2}$ composites at different sintering temperatures

hardness increases with increasing the doping percentage of $\mathrm{ZrO}_{2}$ while the concentration of CTS is decreased and the maximum hardness is found to be $536 \mathrm{MPa}$ for $10 \mathrm{wt} . \%$ of $\mathrm{ZrO}_{2}$ and $90 \mathrm{wt} . \%$ of CTS. This may due to the higher mechanical strength of $\mathrm{ZrO}_{2}$, small grain size and higher relative density of the composite [26]. The difference in porosities of materials is an important factor leading to differences in the hardness. The pores in the sintered solid were eliminated and homogeneous microstructure was acquired with increasing temperature. In this study, it is also observed from table 1 and fig. 2 that, with increasing the sintering temperature the hardness increases and maximum (536 MPa) was obtained at higher sintering temperature $\left(180^{\circ} \mathrm{C}\right.$ for 3 hours in air). 
Therefore, the incorporation of $\mathrm{ZrO}_{2}$ into CTS powder significantly improves the mechanical strength of the prepared composites which could be a possible applicant for biomedical applications.

\section{CONCLUSIONS}

This research studied the structural and mechanical properties of $\mathrm{x}$ wt $\% \mathrm{CTS}+\mathrm{y} \mathrm{wt} \% \mathrm{ZrO}_{2}$ composites $(\mathrm{x}=98,96$, 94, 92, 90 and $\mathrm{y}=2,4,6,8,10)$ synthesized by ball milling method in terms of XRD and Vickers hardness analysis, respectively. The composites have been sintered at three different temperatures $100^{\circ} \mathrm{C}, 150^{\circ} \mathrm{C}$ and $180^{\circ} \mathrm{C}$ for 3 hours in air. The XRD results confirm the crystalline structure of the sintered composites having tetragonal phase. The doping of $\mathrm{ZrO}_{2}$ into CTS slightly changes the main phase as well as decreases the grain size of the composites. The experimental data of Vickers hardness analysis showed that the hardness increases with increasing the doping percentage of $\mathrm{ZrO}_{2}$ while the concentration of CTS is reduced and the maximum (536 Mpa) is obtained for $90 \mathrm{wt} \%$ CTS and $10 \mathrm{wt} \% \mathrm{ZrO}_{2}$ composite sintered at $180^{\circ} \mathrm{C}$. This enhancement of Vickers hardness opens a new window for CTS used in bone tissue engineering.

\section{ACKNOWLEDGEMENT}

The authors acknowledge Materials Science Division, Atomic Energy Center, Dhaka for providing the experimental laboratory facilities.

\section{REFERENCES}

[1] Hirotaka, M., Toshihiro, K., Masayuki, N., \& Minoru, U., "Preparation of bone like apatite composite for tissue engineering scaffold," Science and Technology of Advanced Materials, 2005, vol. 6, pp. 48-53.

[2] Rose, F. R. A. J., \& Oreffo, R. O. C., "Bone tissue engineering: hope vs hype. Biochemical and Biophysical Research Communications," 2002, vol. 292, pp. 1-7.

[3] Du, C., Cui, F. Z., Zhang, W., Feng, Q. L., Zhu, X. D., \& Groot, K. D., "Formation of calcium phosphate/collagen composites through mineralization of collagen matrix. Journal of Biomedical Material Research Part A, 2000, vol. 50, pp. 518-527.

[4] Kikuchi, M., Itoh, S., Ichinose, S., Shinomiya, K., \& Tanaka, J., "Self-organization mechanism in a bone-like hydroxyapatite/collagen nanocomposite synthesized in vitro- and its biological reaction in vivo," Biomaterials, 2001, vol. 22, pp. 1705-1711.

[5] Raimondi, M. T., Moretti, M., Cioffi, M., Giordano, C., Lagana, F. K., \& Pietrabissa, R., "The effect of hydrodynamic shear on 3D engineered chondrocyte systems subject to direct perfusion," Biorheology, 2006, vol. 43, pp. 215-222.

[6] Zhong Z. K., \& Sun, X. Z. S., "Properties of soy protein isolate/polycaprolactone blends compatibilized by methylene diphenyl diisocyanate," Polymer, 2001 vol. 42, pp. 6961-6969.

[7] Kenawy, E.-R.S., Azaam, M.M., Saad-Allah, K.M., "Synthesis and antimicrobial activity of $\alpha$ aminophosphonates containing chitosan moiety," Arabian Journal of Chemistry, 2015 vol. 8, pp. 427-432.

[8] Kumar, M.N., Muzzarelli, R.A., Muzzarelli, C., Sashiwa, H., Domb, A.J., "Chitosan chemistry and pharmaceutical perspectives," Chemical Reviews, 2004, vol. 104, pp. 6017-6084.

[9] Swetha, M., Sahithi, K., Moorthi, A., Srinivasan, N., Ramasamy, K., Selvamurugan, N., "Biocomposites containing natural polymers and hydroxyapatite for bone tissue engineering," International Journal of Biological Macromolecules, 2010, vol. 47, pp. 1-4.

[10] Agnihotri, S.A., Mallikarjuna, N.N., AminabhavI, T.M., "Recent advances on chitosan-based micro- and nanoparticles in drug delivery. Journal of Controlled Release,” Official Journal of the Controlled Release Society, 2004, vol. 100, pp. 5-28.

[11] Danielsen, S., Strand, S., De Lange Davies, C., Stokke, B.T. (2005). Glycosaminoglycan destabilization of DNA-chitosan polyplexes for gene delivery depends on chitosan chain length and GAG properties. Biochimica et Biophysica Acta, 2005, vol. 1721,pp. 44-54.

[12] Di Martino, A., Sittinger, M., Risbud, M.V., "Chitosan: a versatile biopolymer for orthopaedic tissue- 
engineering,” Biomaterials,2005. Vol. 26,pp. 5983-5990.

[13] Ishihara, M., Nakanishi, K., Ono, K., Sato, M., Kikuchi, M., Saito, Y., Yura, H., Matsui, T., Hattori, H., Uenoyama, M., "Photocrosslinkable chitosan as a dressing for wound occlusion and accelerator in healing process,” Biomaterials, 2002, vol. 23, pp. 833-840.

[14] Vandevord, P.J., Matthew, H.W., Desilva, S.P., Mayton, L., Wu, B., Wooley, P.H., "Evaluation of the biocompatibility of a chitosan scaffold in mice," J Biomed Mater Res, 2002, vol. 59, pp. 585- 590.

[15] Gkioni, K., Leeuwenburgh, S. C., Douglas, T. E., Mikos, A. G., \& Jansen, J. A., "Mineralization of hydrogels for bone regeneration," Tissue Engineering Part B Reviews, 2010, vol. 16, pp. 577-585.

[16] Li, B. Q., Hu, Q. L., Qian, X. Z., Fang, Z .P., \& Shen, J. C., "Bioabsorbable chitosan/hydroxyapatite composite rod for internal fixation of bone fracture prepared by in situ precipitation," Acta Polymerica Sinica, 2002, vol. 6, pp. 828-833.

[17] Wang, S., Hu, Y., Wang, Z., Yong, T., Chen, Z., \& Fan, W., 'Synthesis and characterization of polycarbonate/ABS/montmorillonite nanocomposites," Polymer Degradation and Stability,2003, vol. 80, pp. $157-161$.

[18] Josset, Y., Oum'Hamed, Z., Zarrinpour, A., Lorenzato, M., Adnet, J. J., \& Laurent- Maquin, D., “ Journal of Biomedical Material Research," 1999, vol. 47, pp. 481-493.

[19] Kar, S., Kaur, T., \& Thirugnanam, A., "Microwave-assisted synthesis of porous chitosan-modified montmorillonite-hydroxyapatite composite scaffold," International Journal of Biological Macromolecules, 2016, vol. 82, pp. 628-636.

[20] Sollazzo, V., Pezzetti, F., Scarano, A., Piattelli, A., Bignozzi, C. A., \& Massari, L., "Zirconium oxide coating improves implant osseointegration in vivo," Dental Materials, 2008, vol. 24, pp. 357-361.

[21] Sultana, R., Yang, J. Z., \& Hu, X. Z., "Deposition of micro-porous hydroxyapatite/ tricalcium phosphate coating on zirconia-based substrate," Journal of the American Ceramic Society, 2012, vol. 4, pp. 1212-1215.

[22] Ebru G, Dilay P, Cuney H, Unlu OA, Nurfer G, "Synthesis and characterization of chtiosan-MMT bio composite systems," Carbohyd Polym, 2007, vol. 67, pp.358

[23] Marguerite R, "Chitin and chitosan: properties and application,” Prog Polym Sci, 2006, vol.31(7), pp.603-632

[24] Julkapli MN, Akil MH, "X-ray powder diffraction (XRD) studies on kenaf dust filled chitosan biocomposites," AIP Conf Proc, 2007, vol.11, pp. 989.

[25] Uwe Holzwarth, Neil Gibson, "The Scherrer equation versus the 'Debye-Scherrer equation," Nature nanotechnology, 2011, vol. 6(9), pp.535-534.

[26] Rajagopalan, Subramanian Ganesh Sundara Raman, S.K. Seshadri, "Influence of crystallite size on the hardness and fatigue life of steel samples coated with electrodeposited nanocrystalline Ni-W alloys," Materials Letters, 2007 vol.61, pp.715-718. 